\title{
DINÂMICA DA DORMÊNCIA E DO CONTEÚDO DE CARBOIDRATOS E PROTEÍNAS EM GEMAS VEGETATIVAS E RAMOS DE UM E DOIS ANOS DE MACIEIRA COM OU SEM FRIO SUPLEMENTAR
}

\author{
DYNAMIC OF DORMANCY AND CARBOHYDRATE AND PROTEIN CONTENT \\ IN VEGETATIVE BUDS AND STEMS WITH ONE AND TWO YEARS OLD OF \\ APPLE TREE WITH OR WITHOUT SUPPLEMENTARY CHILL
}

\author{
Ruy Inacio Neiva de CARVALHO \\ Orientador(a): Prof. Dr. Flávio ZANETTE \\ (Departamento de Fitotecnia e Fitossanitarismo)
}

\begin{abstract}
RESUMO
O presente trabalho objetivou caracterizar a dinâmica da dormência e do conteúdo de carboidratos e proteínas em gemas e porções de ramos adjacentes às gemas de um e dois anos de idade de macieira da cultivar 'Imperial Gala' com ou sem frio suplementar, coletados em um pomar em alta densidade. As amostras foram coletadas de macieiras no município de Porto Amazonas/PR em intervalos de 21 dias de abril a agosto de 2000. O monitoramento da intensidade da dormência foi realizado pelo teste biológico de estacas de nós isolados. Os ramos coletados foram divididos em dois grupos sendo um testemunha e outro que recebeu o tratamento com 1.440 horas de frio suplementar de 4 a $7^{\circ} \mathrm{C}$. Em cada data de coleta, gemas e porções de ramos adjacentes às mesmas foram separados para análise de sua composição de carboidratos e proteínas. Paralelamente, foram realizados a análise morfológica, o monitoramento da umidade e do conteúdo em cálcio, magnésio e fósforo de gemas e ramos. Seis experimentos foram realizados num delineamento experimental de parcelas subdivididas no tempo com o fator principal arranjado em blocos casualizados. Adotou-se como fator principal o tratamento ou não com frio suplementar e como subparcela as datas de coleta de ramos com três repetições para as análises do conteúdo de carboidrato e proteínas ou quatro repetições para o teste biológico. Avaliou-se o conteúdo em carboidratos solúveis e insolúveis totais, glucose, frutose e sorbitol. A morfologia interna de gemas de dois anos caracterizou um pequeno desenvolvimento de um ramo no interior da mesma, distanciando a região meristemática da inserção da gema no caule. A dormência mais profunda de gemas de um ano ocorreu em julho e de gemas de dois anos ocorreu no final de maio, porém sem um pico tão definido quanto às gemas de um ano. A suplementação com 1.440 horas de frio de 4 a $7^{\circ} \mathrm{C}$ foi efetiva para a redução do tempo médio de brotação das gemas de um ou dois anos de idade. Existe uma variação do conteúdo de carboidratos e proteínas ao longo da dormência de gemas de macieira e as dinâmicas de variação são independentes. O tratamento com frio suplementar alterou a dinâmica do conteúdo de carboidratos mas não alterou a dinâmica do conteúdo de proteínas. De maio até agosto, o sorbitol foi o carboidrato presente em maior porcentagem nas gemas e ramos de um e dois anos de idade e que sofreu as maiores variações de dinâmica de conteúdo após o tratamento com frio suplementar, principalmente no início da dormência. Apesar de haver redução do conteúdo de carboidratos solúveis totais nas gemas de um ano, ocorreu acúmulo de glucose e frutose durante a dormência. O tratamento com frio durante a dormência (maio a julho) promoveu as maiores alterações no conteúdo de carboidratos solúveis. O tratamento tardio, na saída da dormência (julho a agosto), com frio suplementar pouco interferiu na dinâmica do conteúdo de carboidratos solúveis.
\end{abstract}

Palavras-chave: Malus domestica, fruticultura, fisiologia, temperatura.

\begin{abstract}
This work aimed to evaluate the dynamic of dormancy and carbohydrate and protein contents in buds and stems with one and two years old of apple tree cv 'Imperial Gala' with or without supplementary chill, collected in a high density orchard. The samples were collected in Porto Amazonas/Paraná/Brazil in intervals of 21 days from april to august, 2000. The variation of dormancy intensity was observed by the biological test of single node cuttings. The stems collected were treated or not with $1.440 \mathrm{~h}$ of chill $\left(4\right.$ to $\left.7^{\circ} \mathrm{C}\right)$. Buds and stems were analysed separately to the determination of the carbohydrate and protein content. The variations of humidity and the $\mathrm{Ca}, \mathrm{Mg}$ and $\mathrm{P}$ content and morphological aspects were also analysed in buds and stems. The experiments were realized in randomized blocks design for factor chill, with factor date of collect a split plot on chill. Three replications were made to carbohydrate and protein content and four replications were made to biological test. The contents of glucose, frutose and sorbitol are also determined. The internal morphology of two years old buds characterized a small development of a stem inside the bud, with the meristematic region located more distant from the insertion of the bud in the stem. One year old buds presented a more intense dormancy in July, while to two years old buds this fact occur at the end of May, however without a defined peak. The supplementary chill was effective to reduce the average time to burst of one and two years old buds. There was a variation in the carbohydrate and protein content during the period of apple buds dormancy and the dynamics of the variations were independents. The dynamic of carbohydrate content was altered by the supplementary chill but the dynamic of protein content was not. Sorbitol was the main carbohydrate in the buds and stems of apple tree from May to August and the carbohydrate that presented the more significant variations after the treatment with cold temperatures, mainly in the begining of dormancy. Although the total soluble carbohydrate content in the one year old buds decreased, occurred an accumulation of glucose and frutose during the dormancy. The chill treatment during the dormancy period (from May to July) promoted the more significant variations in the soluble carbohydrate content. The chill treatment during the end of dormancy (from July to August) promoted less intense variations in the soluble carbohydrate content. Key- words: Malus domestica, fruit production, physiology, temperature.
\end{abstract}

